\title{
ОСОБЕННОСТИ ИСПОЛЬЗОВАНИЯ ЯЗЫКОВОЙ ИГРЫ В ЭКОНОМИЧЕСКОМ МЕДИАТЕКСТЕ
}

\section{PECULIARITIES OF USING A LANGUAGE GAME IN AN ECONOMIC MEDIA TEXT \\ E. Burdovskaya \\ E. Popova}

Summary: The authors attempted to analyze theoretical sources in order to clarify the term «language game» in this article. The article considers ways to enhance the rational content of economic material through game accentuation of specific information fragments of the media text. Examples of integrating economic terminology into the media text using a language game are given.

Keywords: economic media text, language game, terminative name, logical-semantic game, game at the phraseological level, syntactic game.

\author{
Бурдовская Елена Юрьевна \\ к.филол.н., ассистент, Российский университет \\ дружбы народов \\ burdovskaya-eyu@rudn.ru \\ Попова Елена Олеговна \\ к.филол.н., ассистент, Российский университет \\ дружбы народов \\ popova-elol@rudn.ru
}

Аннотация: В данной статье авторы предприняли попытку анализа теоретических источников с целью уточнения термина «языковая игра». Рассматриваются способы усиления рационального содержания экономического материала за счёт игровой акцентуации конкретных информационных фрагментов медиатекста, приводятся примеры интеграции экономической терминологии в медиатекст с помощью использования языковой игры.

Ключевые слова: экономический медиатекст, языковая игра, терминированное наименование, логико-семантическая игра, игра на фразеологическом уровне, синтаксическая игра.

а также к языковым играм Л. Витгенштейн относил упрощенные модели употребления слов, которые с помощью постепенного усложнения демонстрировали языковую динамику [8;167].

Исследователь А.П. Сковородников отмечает, что языковая игра выступает в качестве наглядного изображения ситуации обсуждения и носит изобразительный характер [10; 86]. О.С. Ахманова рассматривает языковую игру как «игру слов», отождествляя ее с каламбуром - типом речи, состоящем из употребления разных значений одной и той же словоформы в ироничном контексте $[1 ; 228]$. М.Н. Кожина называет языковой игрой нестандартное употребление языковых единиц для создания остроумных высказываний $[4 ; 289]$.

Т.В. Матвеева под языковой игрой понимает речевое поведение с определенным набором установок, используемых для достижения эффекта воздействия на рецепиента. Воздействие, по мнению исследователя, может достигаться в ходе контекстуальных преобразований средств языка и расширения области их применения [5].

Под языковой игрой можно рассматривать и лингвистические игры - сознательное нарушение лексических норм и правил языкового поведения, деформацию речевых клише для достижения экспрессии текстов. На лексическом уровне языковая игра достигается за счет использования паронимов и антонимов, лексических повторов, полисемии и омонимии. На уровне морфологии языковая игра достигается путём использования не- 
стандартных грамматических форм лексических единиц, зачастую противоречащих морфологическим нормам. Языковой игре также свойственно преобразование прецедентных текстов. Соответственно, можно говорить о том, что в новостном субдискурсе языковая игра используется с целью воздействия на рецепиента. Экспрессия достигается за счёт использования нетипичного контекста игровой единицы. В ходе контекстно-семантических преобразований выражение приобретает новый смысл, понятный на интуитивном уровне для рецепиента.

В экономическом медиатексте языковая игра, с одной стороны, может рассматриваться как стилистический приём - неканоническое использование языковых средств, с другой стороны - это использование скрытых прагматических и эстетических возможностей языковых знаков.

Возросший за последние годы интерес читателей-непрофессионалов к экономической информации заставляет журналистов искать новые способы интеграции терминологии. Информационная компрессия, свойственная новостному материалу, не позволяет постоянно делать расшифровку экономических терминов для обывателя, поэтому отправитель информации вынужден искать нестандартный подход использования языковых единиц, чтобы читатель мог вскрыть прагматические интенции, содержащиеся в сообщении. Таким образом, языковая игра в экономическом медиатексте усиливает рациональное содержание материала за счёт игровой акцентуации конкретных информационных фрагментов, прагматика которых значима как для автора сообщения, так и для реципиента. Кроме того, в современном экономическом медиатексте языковая игра выступает в качестве авторского феномена, возникающего благодаря языковой компетенции журналиста.

Примером использования языковой игры может послужить статья о ликвидных российских акциях «Нефть не выдержала двоих». Игровая заголовочная микроформа в данном примере выступает на лексико-фразеологическом уровне, а также является составным компонентом композиционного блока, в качестве которого выступает лид статьи: «На этой неделе российские фондовые индексы снизились. Быстрый рост чен на нефть смог приподнять курс рубля, но не акции, оседавшие под впечатлением событий в США» [7].

Из примера следует, что профессиональное терминированное наименование «снижение фондовых индексов» вводится в текст через использование в языковой игре «нефть не выдержала двоих» основополагающего фактора функционирования самого понятия - «нефть», рост цен на которую смог отразиться на увеличении курса российской валюты, но никак не способствовал росту цен на акции [8; 168].
В статье «Биткойн угодил в зону турбулентности» перифраз устойчивого выражения способствует «игровому» окрашиванию текста статьи. «В последние несколько дней рынок криптовалют переживает резкие взлеты и падения...» [9]. Терминированное наименование «динамика курса криптовалюты» при включении в статью обыгрывается с помощью языковой игры, микроформа которой выступает на фразеологическом уровне за счет синтаксической игры с сочетаемостью: резкие взлеты и падения цены на биткоин сравнивается автором с турбулентностью, что способствует упрощению восприятия экономической информации [8; 168].

В статье «Дивиденды размывает серной кислотой» представлена информация о намерения руководства МК «Норильский Никель» произвести корректировку формулы дивидендов в связи с растущими показателями долга: «Гендиректор компании Владимир Потанин (владеет 30,3\% ГМК) предложил снизить верхний порог коэффичиента чистый долг / EBITDA до 2 с нынешних 2,2, при его превышении на выплаты пойдет всего $30 \%$ EBITDA» $[2 ; 9]$.

При использовании игровой микроформы на уровне микротекстовой организации происходит логико-семантическая игра со значением, так как никель - это металл, у которого практически невозможно провести реакцию с серной кислотой. Соответственно, можно говорить о двойной смысловой нагрузке на заголовок. Во-первых, заголовок сразу же наталкивает на мысль, что руководству предприятия «Норильский Никель» будет очень сложно убедить собственников согласиться с предлагаемыми условиями. Во-вторых, заголовок является своеобразным способом включения в текст статьи терминированного наименования «коэффициент чистый долг / EBITDA». Языковая игра используется, чтобы проиллюстрировать прямо пропорциональную взаимосвязь между показателем деловой нагрузки на предприятие, ее способностью удерживать долг на уровне, не снижающим инвестиционный рейтинг, и способностью выплачивать дивиденды. Соответственно снижение верхнего порога коэффициента чистый долг / EBITDA должно ассоциироваться со снижением выплат акционерам компании [8; 169].

В статье издания «Коммерсантъ» «Спрос уезжает с дач» языковая игра используется для включения терминированных наименований «снижение платежеспособности» и «неликвидное предложение», которые являются основными показателями возможности совершения покупки загородной недвижимости: «Вместе со снижением платежеспособности затянувшееся падение рынка обеспечивает большая доля неликвидного предложения, на долю которого, по оценкам аналитиков, сейчас приходится 80\% от общего объема предложения. Речь в первую очередь идет о домах с неудачным расположе- 
нием, большой площадью или низкими качественными характеристиками» [6]. В связи с этим синтаксическая игра с сочетаемостью, используемая в приведенном примере языковой игры, необходима для проведения параллели между значениями используемых в тексте терминированных наименований и понятием «спрос», основными параметрами которого они выступают [8; 169-170].

Логико-семантическая игра со значением используется в статье ««Магнит» притянул инвесторов на скидку»: «Ритейлер проводит SPO с дисконтом к рынку» [11; 10]. Языковая игра выступает в качестве пояснения нескольких терминов, используемых в тексте: «ритейлер», «SPO», «дисконт». «Ритейлер»- владелец розничной сети мага- зинов = «Магнит»; «SPO»- публичное размещение акций, принадлежащих изначальным акционерам или венчурным фондам, на рынке ченных бумаг, фактически, их продажа = «притянул инвесторов»; «дисконт»- скидка [8; 170].

Таким образом, можно говорить о том, что применение языковой игры в экономическом медиатексте расширяет возможность преобразования информации. Использование языковых приемов происходит, преимущественно, в заголовках и тематических подзаголовках. Экспрессивная акцентуация в заголовках повышает интерес к материалу, а за счет редукции игровой формы происходит понимание экономической терминологии читателем-непрофессионалом.

\section{ЛИТЕРАТУРА}

1. Ахманова 0.С. «Лингвистическая лексика», 4-е издание, Рипол Классик, $2013-474$ C.

2. Джумайло А. Дивиденды размывает серной кислотой / А. Джумайло // Коммерсантъ. - 2017. - № 217. - 22 ноября. - С. 9.

3. Кириленко Н.П., Сафронова Т.И. Место языковой игры в текстах современной рекламы / Н.П. Кириленко, Т.И. Сафронова // Современные проблемы науки и образования. - 2013. - № 5. - С. 56.

4. Кожина М.Н. 0 диалогичности письменной научной речи: Учебное пособие по спецкурсу / М.Н.Кожина. - Пермь: 1986. - С. 289.

5. Ласкова, М.В. Лингвокультурные особенности языковой игры в рекламной картине мира [Электронный ресурс] : монография / Ю.В. Попова, М.В. Ласкова .— Ростов н/Д. : Изд-во ЮФУ, 2013 .— 128 с.

6. Мерцалова А. Спрос уезжает с дач / А. Мерцалова // Коммерсантъ [Электронный ресурс]: Коммерсанъ - Электрон. дан. - 2017. - 20 июня. - Режим доступа: https://www.kommersant.ru/doc/3330490 (дата обращения 20.06.17)

7. Нефть не выдержала двоих // Коммерсантъ [Электронный ресурс]: Коммерсанъ - Электрон. дан. - 2017. - 20 мая. - Режим доступа: https://www. kommersant.ru/doc/3303548 (дата обращения 20.05.17)

8. П Попова Елена Олеговна. Экономическая пресса России: типология, история, лексика: диссертация ... кандидата Филологических наук: 10.01 .10 / Попова Елена Олеговна; [Место защиты: ФГАОУ В0 «Российский университет дружбы народов»], 2018.- 283 с.

9. Сарханянц К. Биткоин угодил в зону турбулентности / К. Сарханянц // Коммерсантъ [Электронный ресурс]: Коммерсанъ - Электрон. дан. - 2017. - 16 июня. - Режим доступа: https://www.kommersant.ru/doc/3328793 (дата обращения 16.06.17)

10. Сковородников А.П. Экспрессивность и выразительность / А.П. Сковородников, Г.А. Копнина // Язык средств массовой информации: Учеб- ное пособие по специализации. Часть 2. - М.: Изд-во Моск. ун-та, 2004. - С. 86.

11. Трутнев 0., Гайдаев В. «Магнит» притянул инвесторов на скидку / О. Трутнев, В. Гайдаев // Коммерсантъ. - 2017. - №213. - 16 ноября. - С. 10. 